This is an open access article under the terms of the CC-BY 3.0 License.

Peer review method: Double-Blind

Date of acceptance: December 07, 2020

Date of publication: January 08, 2021

Review article

DOI: https://www.doi.org/10.47305/JLIA2163102m

\title{
THE ESCALATION OF CONFLICT BETWEEN ARMENIANS AND AZERBAIJANIS AND THE PROBLEMS OF PEACEFUL RESOLUTION OF THE NAGORNO-KARABAKH WAR
}

\author{
Valeri Modebadze \\ St. Andrew the First-Called Georgian University of the Patriarchate of Georgia, Georgia \\ ORCID iD: https://orcid.org/0000-0002-1232-4841 \\ valery_4@yahoo.com
}

\begin{abstract}
This article explains why it is so difficult to achieve peace in Nagorno-Karabakh and what factors prevent the peaceful resolution of the conflict. This conflict is very difficult to resolve because the conflicting parties have contradictory geopolitical interests and cannot achieve consensus during negotiations. We have to take into account Russia's geopolitical interests in South Caucasus that Kremlin is interested in freezing this conflict to weaken both states, Azerbaijan and Armenia, and bring them back to Russia's orbit. Moscow aims to establish firm control over South Caucasus which was viewed in the past as a 'Russian backyard'. Russia still views South Caucasus as its zone of influence and tries to bring this region back into Russia's orbit.
\end{abstract}

Keywords: Nagorno-Karabakh; Conflict; South Caucasus; Russia; Armenia; Azerbaijan

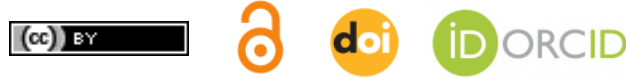




\section{INTRODUCTION}

Since 27 September 2020 new clashes erupted in the breakaway region of Nagorno-Karabakh, which quickly escalated into a full-scale war. The fighting between Armenian and Azerbaijani troops lasted for six weeks. This conflict is often described as the first war in the history of modern warfare that has been won almost entirely with the help of drones. It is still unknown which side started the war, Yerevan and Baku blame each other for the escalation of the conflict. Despite efforts of the Russian brokered ceasefire, fighting continued until the $10^{\text {th }}$ of November 2020 and neither side was willing to stop the war. On 9 October 2020, the Foreign Ministers of Russia, Armenia, and Azerbaijan, Sergey Lavrov, Zograb Mnatsakanyan, and Jeyhun Bairamov, met in Moscow to end the conflict in Nagorno-Karabakh. After about ten hours of negotiations, the parties agreed to a humanitarian ceasefire, which came into force at midnight on 10 October 2020. Nevertheless, the hostilities did not cease, and fighting continued in the breakaway region.

The destruction has swept through this region with devastating force. Many towns and villages were razed to the ground and people were forced to leave front-line settlements. As a result of the bloody war, many settlements were transformed into ghost towns. The streets and houses are abandoned and deserted. The sound of distant artillery fire could be heard everywhere during the war. Those who decided to stay in the conflict zone were consigned to underground life in the shelters and bunkers. Both sides, Armenia and Azerbaijan, used long-range missiles to target civilian territories and populated areas.

\section{THE EMERGENCE OF WAR IN THE 1990s AND THE NEGOTIATION PROCESS TO END THE CONFLICT}

This conflict started 30 years ago when the Soviet Union collapsed and ethnic tensions emerged in the South Caucasus. A brutal war erupted between Armenia and Azerbaijan after the breakdown of the Soviet Union, which finally ended with a ceasefire in 1994 after the deaths of more than 30.000 troops. Ethnic Armenians won control of the Nagorno-Karabakh region after a bitter and bloody war. They cemented their rule over this mountainous region, declaring independence and forging overland links with Armenia. With the help of Yerevan, Nagorno-Karabakh maintained control over its territory. After the 1994 exodus of ethnic Azerbaijanis, the area has acquired an exclusive Armenian character. According to the last Soviet survey, which was conducted in 1989, Armenians accounted for $77 \%$ of the population in Nagorno-Karabakh, while Azerbaijanis accounted for $22 \%$. However, in the seven adjacent districts surrounding Nagorno-Karabakh, roughly $95 \%$ of the population was ethnic Azerbaijani. Regardless of the demographic composition, the two communities, Armenians and Azerbaijanis lived 
and coexisted peacefully during Soviet times. But relations began to deteriorate between them in the final years of the Soviet Union. Armenia began to claim lands from Azerbaijan, ethnic tensions erupted and the trust that has been constructed for so many years suddenly evaporated within weeks. Hostilities between Armenians and Azerbaijanis escalated into a full-scale war in 1992. Many atrocities and war crimes were committed by both sides and countless villages and towns were razed to the ground.

A Ceasefire was signed in 1994 and peace talks began between the conflicting sides with the help of the OSCE Minsk group and three countries, Russia, France, and the USA acted as mediators in this conflict. In the intervening 30 years, nothing has been done to resolve the status of Nagorno-Karabakh and end the conflict through peaceful means. Peace talks were ongoing for 27 years but without any kind of progress. The OSCE Minsk Group, which is co-chaired by France, the Russian Federation, and the United States, tried to bring all sides to a peace settlement, but all attempts to solve the conflict peacefully were futile. The 2020 Nagorno-Karabakh war was the result of diplomatic failure. There have been periodic violence and military skirmishes between the two conflicting sides. Over the last years numerous proposals were negotiated, but the most feasible road map, which is known as the Madrid Principles, was introduced in 2007.

That deal entails the following: First, districts surrounding the Nagorno-Karabakh should be returned to the Azerbaijani control; Second, Nagorno-Karabakh should be granted an interim status and provided with security guarantees and self-governance; Third, a corridor has to be established to link Armenia to Nagorno-Karabakh; Fourth, the final status of Nagorno-Karabakh should be determined through a legally binding expression of will; Fifth, all internally displaced people, and refugees should be granted the right to return to their former places of residence; Finally, international security guarantees in the form of peacekeeping operations should take hold across the region.

Although the Madrid Formula presents the most feasible roadmap towards a peaceful resolution, the exact terms of each principle have been a matter of rigorous interpretation and negotiation. The biggest disagreement during negotiations was the status of Nagorno-Karabakh. Yerevan has always rejected Nagorno-Karabakh's subordination to Baku and demanded guarantees of independence before engaging in any significant concessions. Meanwhile, Azerbaijan always refused to concede its territory to Armenia and thought that the independence of Nagorno-Karabakh was unacceptable and represented a serious threat to the territorial integrity of Azerbaijan. While Armenia stresses the importance of self-determination to resolve the status of Nagorno-Karabakh, Azerbaijan insists on maintaining its territorial integrity. As the President of Azerbaijan Ilham Aliev stated during the interview, self-determination is an important principle of international law, but it should not violate the territorial integrity of the country (Toradze 2020). 


\section{FACTORS THAT CAUSED THE ESCALATION OF RECENT CONFLICT}

When the ethnic Armenian forces won the first war in 1994, they did not just take control of the Nagorno-Karabakh region, they also occupied seven surrounding districts of Azerbaijan forcing out the ethnic Azeri population. Armenians too had to flee areas that remained under Azerbaijani control. These Azerbaijani districts, which are now largely depopulated, served as an important security buffer for Nagorno-Karabakh. Azerbaijan has taken an uncompromising stance demanding the return of occupied territories.

In 2011 Russia proposed to start the Madrid principles with the return of Azerbaijani districts surrounding Nagorno-Karabakh. According to Lavrov's plan, Armenians had to start the handover of 5 districts of Azerbaijan in stages and Russian troops were to be deployed into the regions under the guise of peacekeeping. According to this plan, five of the seven areas were to be returned to Azerbaijan.

However, Armenia refused to make any concessions to Azerbaijan, and as a result, negotiations have remained at the deadlock since. There were numerous attempts to revive peace talks but much of it was a futile attempt. Armenians were satisfied with the status-quo and therefore denied making any concessions to Azerbaijan. If initially, after the end of the 1994 war, Armenians viewed the 7 adjacent districts of Nagorno-Karabakh as a bargaining chip during negotiations and were ready to make concessions to Azerbaijan, later any compromise to Azerbaijan was perceived as an act of betrayal of Armenia. Before the outbreak of the war, there was a widespread view in the Armenian society that all territories, even the seven adjacent districts of Nagorno-Karabakh, should remain under the firm control of Armenia.

The Armenian leadership in Nagorno-Karabakh added fuel to the fire when it decided to incorporate the seven Azerbaijani districts into its administration. New provisional borders were drawn, new roads were constructed and the abandoned Azerbaijani settlements were given Armenian names. Meanwhile, historical sites that were located in the Azerbaijani districts were embedded in Armenian banknotes. This was a clear indication and sign that Armenia did not intend to solve the Karabakh conflict peacefully and make any concessions to Azerbaijan. On top of everything, the Armenian government started to resettle ethnic Armenians from various parts of the world in the occupied territories of Azerbaijan. Before the outbreak of the war, the Armenian government had a plan to resettle Lebanese Armenians in the occupied territories of Azerbaijan and to create Armenian settlements in the Azerbaijani districts. These dangerous and provocative actions illustrated that Armenia was effectively annexing $20 \%$ of the Azerbaijanian Land. Not surprisingly any attempt of negotiations failed and peace talks remained paralyzed. Despite the many efforts of the international community to revive the peace talks, nothing could be done to reach a consensus among the conflicting parties. 
Political rhetoric became increasingly belligerent on both sides. Azerbaijan many times warned the international community that it intended to liberate occupied territories by force, while Armenia threatened to take even more territories in the next war. Armed conflict was inevitable and in September 2020 large-scale hostilities erupted in the Nagorno-Karabakh region. Both sides, Armenia and Azerbaijan have used sophisticated weapons and missiles to gain a strategic advantage in this bloody war. Azerbaijan has achieved total air superiority thanks to the drones that it bought from Turkey and Israel. Azerbaijan has used two types of drones during the war: The Turkish made Bayraktar drones and Israeli made 'Kamikaze' drones. Over the last years, Turkey has increased its efforts to strengthen its influence in the Caucasus region. When the conflict broke out in Nagorno-Karabakh, Turkey saw an opportunity and offered moral, political, and military support to Azerbaijan. In summer 2020, the two states held joint military exercises in Azerbaijan, and Turkey's supply of weapons to Azerbaijan dramatically surged, which included sophisticated weapons and advanced drones. It seems that this conflict was carefully planned for years by Turkish and Azerbaijani military officials. Emboldened by Turkish support, Azerbaijan has decided to retake the Nagorno-Karabakh region by force.

While Azerbaijan has made some modest territorial gains, it hasn't swept the board as its military leaders had originally hoped. The Second Karabakh War highlighted the significant technological superiority of the Azerbaijani army. The armed forces of Azerbaijan managed to advance rapidly on certain sections of the front and regained control over a significant part of Nagorno-Karabakh, namely, its southern section. Azerbaijani army captured nearly the entire area near the border with Iran. Azerbaijan was able to gradually retake a significant part of the occupied territories around the Nagorno-Karabakh Autonomous Region, including the Jabrayil, Zangilan, Fuzuli, and Qubadli districts. After liberating these territories, the armed forces of Azerbaijan advanced rapidly towards the Lachin corridor, which is a key supply line for the Armenians. The seizure of the Lachin corridor was the main objective of the armed forces of Azerbaijan because without the Lachin corridor Armenia's main artery to Nagorno-Karabakh would be cut off. Heavy fighting took place in the directions of Khojevand (Martuni) and Lachin, as well as on the northern front. Armenians did not manage to launch any effective counteroffensive and were constantly retreating during the war. The culmination of the war was the capture of the historic center of Karabakh, Shusha, by Azerbaijan, after which the leaders of Armenia, Azerbaijan, and Russia signed a deal to end the Nagorno-Karabakh war (Bragvadze 2020). 


\section{THE CONSEQUENCES OF 2020 NAGORNO-KARABAKH WAR AND RUSSIA'S GEOPOLITICAL INTERESTS IN SOUTH CAUCASUS}

Armenia had suffered significant military setbacks at the hand of Azerbaijani forces. Not only has it lost most of the Azerbaijani districts it occupied in 1993, but also a significant part of Nagorno-Karabakh. Under the peace deal, the borders of NagornoKarabakh have been redrawn and the armed forces of Armenia must leave the Armenian-controlled territories surrounding Nagorno-Karabakh by 1 December 2020. While the Azerbaijanis called the deal a victory, Armenians have called it a national humiliation. Armenia's Prime Minister Nicole Pashinyan described the deal as an unbelievably painful decision.

Russia is a military ally of Armenia and maintains a military base in this country. Armenia is a member of Russian led Eurasian Economic Union, as well as the Collective Security Treaty Organization (CSTO). The CSTO is a military-political block under Russian auspices. It was expected that Russians would help their ally Armenia in this war. Putin, however, has refused to provide support to Armenians, because fighting was taking place not on the Armenian soil but in the Karabakh region, which legally belongs to Azerbaijan. So, in legal terms, Russia could not get involved in this conflict because the war was not widespread on the Armenian territory. That explains part of the reason why Russia refused to help Armenia and remained neutral in this conflict. The other reason is that Putin detests the pro-western Armenian government and the Armenian prime minister Pashinyan for his anti-Russian activities. When Pashinyan came to power in 2018 he decided to get rid of corrupt pro-Russian politicians and government officials and decided to replace them with pro-Western lawmakers. With these new reforms, Pashinyan intended to diminish Armenian's reliance on Russia. However, these AntiRussian actions have angered Putin and have raised alarm bells in the Kremlin (Oborne and Westad 2020). Kremlin would like to reverse the process and bring back pro-Russian politicians to power.

Interestingly, the former president of Armenia, Kocharyan who is viewed as Pashinyan's rival and enjoys very good relations with the Russian political establishment, is back in the political scene. Russia is looking forward to changing the political leadership in Yerevan and therefore, does not offer any kind of help to Pashinyan. After the war, angry people in Yerevan stormed the parliament and demanded the resignation of Pashinyan for giving up the territory to Azerbaijan. Because of these large-scale protests, it is unlikely that Pashiniyan will remain in power.

The final reason for Russia's non-involvement in the Nagorno-Karabakh conflict is related to the geopolitical objectives of the Kremlin in the South Caucasus region. Russia's actions should be analyzed from the geopolitical point of view, Moscow is not interested in solving the conflict between Armenians and Azerbaijanis. It is in Kremlin's interest to freeze the Nagorno-Karabakh conflict to weaken both states, Azerbaijan and 
Armenia, and bring them back to Russia's orbit. Moscow aims to establish firm control over South Caucasus because of its enormous strategic importance as a bridge between Europe and Asia. Moscow does not like the fact that foreign powers try to gain a foothold in this strategically important region, which was viewed before as a 'Russian backyard'. South Caucasus borders energy-rich regions such as the Middle East, the Caspian Basin, Central Asia, and the shortest route from Europe to Asia pass through this region. South Caucasus is a very important transport corridor and a vital link between East and West. This region can play a very important role in increasing trade, economic and commercial links between Asia and Europe. Over the last years, the development of transportation infrastructure has increased considerably the strategic significance of this region. Russia wants to strengthen its influence in the post- Soviet space and therefore, sees the West and other great powers as its geostrategic competitors.

The Cold War, which ended in Europe in the 90s, is now raging in South Caucasus. Now, Caucasus is the region where geopolitical and geo-economics interests of great powers collide with each other. They all try to gain a foothold in this strategically important region. Russia views all other powers as its rivals and tries to bring back this region under its firm control (Modebadze 2018).

The Russian government knows that frozen conflicts are a serious headache for Caucasian states and prevent their integration into Euro-Atlantic structures. Kremlin views the expansion of NATO as a threat and wants to prevent the integration of Caucasian states in this organization. Russia's main objective is to stop the eastward expansion of NATO. NATO enlargement and moving military infrastructure closer to the Russian borders are seen as foreign policy threats. Russia is aware that as long as the South Caucasian states are involved in ethnic conflicts and wars, their chances of integration into NATO and Euro-Atlantic structures is very low. Thus, it is in Russia's interest to maintain political, economic, and social instability in the Caucasus to prevent the expansion of NATO and the incorporation of Caucasian states into NATO.

Russia is the only winner of the Nagorno-Karabakh war. The deal that was signed on 9 November benefits Russia. It plays a vital role in strengthening Russia's presence in the South Caucasus region. This deal allows Russia to deploy 'peacekeeping forces' to the Nagorno-Karabakh region (Dyer 2020). By sending peacekeeping forces to Nagorno-Karabakh Russia establishes a permanent military presence in Azerbaijan. Apart from this, Russia gains the right to control the Lachin corridor, which plays a crucial role in connecting Armenia to Nagorno-Karabakh. Lachin corridor is used by Armenia as a logistical route to send supplies into Nagorno-Karabakh. By controlling this strategically important corridor Russia has a chance to gain greater leverage over Armenia. Isolated and impoverished Armenia will become more dependent on Russia and its sovereignty will be jeopardized. As Russia's influence grows in the region, Armenia and Azerbaijan may become the satellite states of Russia in the future. 
Another corridor, that Russia is going to use as a political weapon and leverage for controlling conflicting parties, is the strategic corridor that will connect Azerbaijan with Nakhichevan and Turkey. This corridor has a great strategic significance for Baku as it will be the shortest route from Azerbaijan to Turkey. According to the deal, Russian FSB's Border Troops have the right to control this corridor, which will play a crucial role in connecting Turkic speaking countries with each other. Azerbaijan and Russia may use this corridor for the implementation of large-scale energy projects. This deal helped Russia to increase its influence in the South Caucasus region (Esipov 2020). This new agreement is unlikely to end hostilities between Armenians and Azerbaijanis. On the contrary, it can provoke a war in the future, as both sides are very much dissatisfied with the fact that now Nagorno-Karabakh is firmly in Russian hands.

\section{CONCLUSION}

As we have seen above, it is very difficult to achieve peace in the South Caucasus and solve the Nagorno-Karabakh conflict peacefully for many reasons. First of all, we should take into account the fact that conflicting sides have contradictory geopolitical objectives and cannot reach a consensus during negotiations. Neither side is willing to make concessions and reach an agreement. We should take into account also Russia's geopolitical and geo-economic interests, the Kremlin would like to establish total control over the South Caucasus and does not want this region to become a European transport and energy corridor. Therefore, Russian authorities will always try to destabilize this region through frozen conflicts. Russia will always support separatist forces in this region to disrupt the realization of new and important megaprojects in the South Caucasus. Kremlin aims to prolong the conflict in Nagorno-Karabakh to achieve its geopolitical objective in South Caucasus - weaken both states, Armenia and Azerbaijan and bring them back into Russia's orbit. 


\section{REFERENCES}

1. Modebadze, Valeri. 2018."EU relations with the South Caucasian countries since the breakdown of Soviet Union". Third International Scientific Conference - Politics Around Caucasus, Proceedings, Tbilisi, https://www.academia.edu/37409208/EU relations with the South Caucasian countries since the breakdown of Soviet Union

2. Bragvadze, Davit.2020."Russian Gambit in the Second Karabakh War". Kviris Palitranewspaper,https://www.kvirispalitra.ge/gisp-blogi/70925-rusuligambiti-yarabaghis-meore-omshi.html

3. Esipov, Vladimir. 2020."Nemeckij èkspert: Mir v Karabahe - ser'eznyj uspeh vnešnej politiki Rossii". Deutsche Welle, https://www.dw.com/ru/nemeckijjekspert-mir-v-karabahe-sereznyj-uspeh-vneshnej-politiki-rossii/a-55565160

4. Dyer, Gwynne. 2020. "Armenia ceasefire: a truce to last". CyprusMail, https://cyprus-mail.com/2020/11/14/armenia-ceasefire-a-truce-to-last/

5. Toradze, Salome. 2020. "Ilham Aliyev - We will not allow the creation of a second Armenian state on the territory of Azerbaijan". First Channel, https://1tv.ge/news/ilham-alievi-ar-davushvebt-somkhetis-meoresakhelmwifos-sheqmnas-azerbaijanis-teritoriaze/

6. Oborne, Peter and Westad, Jan-Peter. 2020. "Caught between Russia and Turkey, Armenians say West has abandoned them". Middle Yeast Eye, https://www.middleeasteye.net/news/armenia-azerbaijan-conflict-russiaturkey-west-abandoned 